\title{
POLA ASUH ORANG TUA DALAM PERKEMBANGAN SIKAP TANGGUNG JAWAB ANAK DI DESA PAREN JEPARA
}

\author{
Hanim Aulia Maghfiroti ${ }^{1}$, Mohammad Kanzunnudin ${ }^{2}$, Sekar Dwi Ardianti ${ }^{3}$ \\ 1,2,3 Universitas Muria Kudus, Kudus, Indonesia \\ 1'hanimaulia25@gmail.com, ${ }^{2}$ moh.kanzunnudin@umk.ac.id, ${ }^{3}$ sekar.dwi.ardianti@umk.ac.id
}

\begin{abstract}
ABSTRAK
Tujuan penelitian ini yakni mendeskripsikan bentuk sikap tanggung jawab anak dalam kehidupan bermasyarakat di Desa Paren Jepara. Penelitian ini menggunakan jenis penelitian kualitatif deskriptif dengan metode studi kasus. Pola asuh orang tua merupakan pola asuh orang tua dalam melaksanakan peranannya sebagai pengasuh, pendidik, serta pendamping bagi anak-anaknya. Jenis pola asuh orang tua ada tiga yakni demokratis, permisif, dan otoriter. Tanggung jawab merupakan sikap yang dimiliki individu untuk melakukan kewajibannya serta siap menanggung segala konsekuensi atas perkataan dan tindakan yang dilakukan. Subjek penelitian ini terbatas pada empat anak SD usia 8-10 tahun dalam perkembangan sikap tanggung jawabnya. Teknik dan instrumen pengumpulan data yang dipakai dalam penelitian ini adalah observasi, wawancara dan dokumentasi. Penelitian ini menggunakan analisis data kualitatif dengan acuan konsep dari Miles dan Huberman. Hasil penelitian ini menunjukkan bahwa pola asuh yang diterapkan orang tua kepada anak menyebabkan perkembangan sikap tanggung jawab anak yang berbeda satu sama lain. Terdapat satu anak yang mendapat pola asuh otoriter mengakibatkan sikap tanggung jawab yang dimiliki anak masih rendah. Satu anak mendapat pola asuh demokratis sehingga anak memiliki sikap tanggung jawab yang baik dan dapat menyelesaikan masalahnya sendiri. Dua anak mendapat pola asuh permisif yang menyebabkan anak miliki sikap tanggung jawab yang cukup baik.
\end{abstract}

Kata Kunci: pola asuh orang tua, sikap tanggung jawab

\section{PARENTING PATTERNS IN DEVELOPING CHILDREN'S RESPONSIBILITY ATTITUDE IN DESA PAREN, JEPARA}

\begin{abstract}
The goal of this study was to describe the form of children's responsible attitude in Desa Paren, Jepara. The study utilized descriptive types of qualitative research by case study methods. A parents' parental pattern is the pattern that parents apply in fulfilling their role as caretakers, educators, and companions to their children. There are three types of parental patterns: democratic, pessimistic, and authoritarian. A child's responsibility is an individual's attitude to do his duty and be prepared to bear all the consequences for the words and actions that they committed. The subject of this study was limited to four 8-10 year-olds children in their responsiveness. The data collection tools used in this study were observations, interviews, and documentation. The study used qualitative data analysis with concept references from Miles and Huberman. The results of this study suggested that parenting trends adopted to children caused the development of responsiveness among children. One child possessed an authoritarian upbringing that resulted in a child's low sense of responsibility. One child had a democratic upbringing that enabled him to have a responsible attitude and be able to solve his own problems. Two children received a permissiveness that resulted in a reasonably good sense of responsibility.
\end{abstract}

Keywords: parenting patterns, attitude of responsibility

\begin{tabular}{|c|c|c|}
\hline Submitted & Accepted & Published \\
\hline 03 Agustus 2021 & 30 September 2021 & 24 November 2021 \\
\hline
\end{tabular}

\begin{tabular}{|l|c|c|}
\hline Citation & $:$ & $\begin{array}{r}\text { Maghfiroti, H.A., Kanzunnudin, M., \& Ardianti, S.D. (2021). Pola Asuh Orang Tua Dalam Perkembangan Sikap } \\
\text { Tanggung Jawab Anak Di Desa Paren Jepara. Jurnal PAJAR (Pendidikan dan Pengajaran), 5(6), 1665-1673. } \\
\text { DOI : http://dx.doi.org/10.33578/pjr.v5i6.8190. }\end{array}$ \\
\hline
\end{tabular}

\section{PENDAHULUAN}

Pendidikan merupakan salah satu hal yang sangat penting untuk membekali anak menghadapi masa depan. Pendidikan mempunyai peran penting dalam pembentukan sumber daya manusia yang cerdas, cakap, kreatif, beriman dan berahklak mulia (Ardianti, dkk, 2017). Keluarga merupakan salah satu lembaga yang mengemban tugas dan tanggung jawab dalam pencapaian tujuan pendidikan umum. Orang tua memiliki peran yang sangat penting dalam perkembangan sikap tanggung jawab anak. Pendidikan pertama yang didapat anak adalah dari keluarganya yang mendidiknya sejak lahir. Tanggung jawab dan kepercayaan orang tua yang dirasakan oleh anak 
akan menjadi dasar peniruan dan identifikasi diri untuk berperilaku.

Belajar adalah kegiatan utama yang yang dilakukan dari seluruh proses Pendidikan yang ada di sekolah yang diharapkan mampu merubah tingkah laku anak (Dewi, 2021). Shochib (1998) mengatakan bahwa pembelajaran seharusnya bersifat fleksibel dan mudah diterima oleh anak, sehingga pada saat proses pembelajaran anak tidak merasa bosan dan mudah dipahami. Jika pembelajaran sukar untuk diterima anak, maka anak akan merasa bosan dan jenuh saat proses pembelajaran berlangsung.

Pola asuh merupakan Pola asuh merupakan pola asuh orang tua dalam melaksanakan perannya sebagai pengasuh, pendidik, serta pendamping bagi anak-anaknya. Pola asuh yang dilakukan orang tua dapat mempengaruhi perkembangan diri anak. Muktadin, (2010) mengatakan bahwa pola asuh adalah interaksi antara anak dan orang tua selama mengadakan kegiatan pengasuhan yang berarti orang tua mendidik, membimbing dan mendisiplinkan serta melindungi anak sehingga memungkinkan anak untuk mencapai tugas-tugas perkembangannya. Kanzunnudin, dkk (2021) pola asuh orang tua adalah salah satu cara orang tua mendidik, merawat, memberikan arahan, dan memberikan bimbingan kepada anak, orang tua satu dengan orang tua lainnya menerapkan pola asuh yang berbeda-beda. Pola asuh orang tua merupakan pola asuh orang tua dalam melaksanakan perannya sebagai pengasuh, pendidik, serta pendamping bagi anak-anaknya. Pola asuh yang dilakukan orang tua dapat mempengaruhi perkembangan diri anak. Pola asuh dikelompokkan dalam 3 tipe menurut Baumrid (dalam Edwards 2012) yakni pola asuh demokratis, pola asuh ototiter dan pola asuh permisif.

Menurut Soraya (2015) Cara orang tua mendidik anak-anaknya memiliki pengaruh yang besar terhadap kegiatan belajar anak. Untuk itu orang tua harus memiliki strategi yang harus dilakukan untuk mengembangkan prestasi belajar anak, diantaranya: cara orang tua mendidik, relasi antar anggota keluarga, suasana rumah, keadaan ekonomi, penegrtian dari orang tua.
Sikap tanggung jawab merupakan sikap yang dimiliki individu untuk melakukan kewajibannya serta siap menanggung segala konsekuensi atas perkataan dan tindakan yang dilakukan. Tanggung jawab terbentuk seiring dengan pertumbuhan dan perkembangan anak. Tanggung jawab berasal dari dalam hati dan kemauan sendiri untuk melakukan kewajiban (Sukirman, 2016). Aisyah (2014) menjelaskan tanggung jawab merupakan suatu sikap atau perilaku yang menuntut siswa untuk menanggung resiko atas segala tindakan dan ucapannya yang diterapkan dalam kehidupan sehari-hari terutama dalam hal belajar. Haris (2017) mengatakan bahwa tanggung jawab merupakan kesadaran manusia terhadap tingkah laku dan perbuatannya yang dilakukan secara sadar dan tidak sadar. Tanggung jawab merupakan sikap yang dimiliki individu untuk melakukan kewajibannya serta siap menanggung segala konsekuensi atas perkataan dan tindakan yang dilakukan.

Sikap tanggung jawab yang dimiliki anak kurang baik untuk anak SD usia 8-10 tahun di Desa paren Jepara, hal ini dikarenakan pola asuh orang tua yang sibuk bekerja sehingga kurang adanya perhatian. Pola asuh orang tua berbedabeda sehingga berpengaruh pada sikap tanggung jawab anak. Hal tersebut dapat menghambat perkembangan sikap tanggung jawab anak yang kurang maksimal memberikan pengasuhan dan pendampingan kepada anak.

Sikap tanggung jawab anak berkembang dengan baik apabila orang tua dapat menerapkan pola asuh yang tepat kepada anak dan lebih perhatian kepada anak. Orang tua perlu berkomunikasi secara efektif dengan anak agar anak lebih terbuka kepada orang tua untuk bercerita mengenai aktivitasnya diluar rumah dan apabila ada permasalahan dapat terselesaikan dengan bermusyawarah bersama (Muslima, 2015). Orang tua perlu membimbing dan membiasakan anak untuk bersikap tanggung jawab di lingkungan keluarga maupun di lingkungan masyarakat supaya anak mengetahui dan paham mengenai sikap tanggung jawab dan menjadi anak yang baik. 


\section{KAJIAN TEORETIS \\ Pola Asuh Orang Tua}

Pola asuh merupakan proses menjadi orang tua, orang tua akan memberikan bantuan dalam segala aspek kehidupan anak termasuk kebutuhan, hiburan, dan yang terpenting adalah pendidikan (Handayani, dkk, 2020). Sukiman (2019) mendefinisikan pola asuh juga merupakan sikap orangtua dalam berinteraksi dengan anaknya yang meliputi cara orangtua memberikan aturan-aturan, hadiah maupun hukuman. Damayanti (2017) pola asuh orang tua adalah suatu cara orang tua dalam mengasuh dan mendidik, serta membina anaknya dengan penuh kasih sayang agar sikap sosialnya dapat berkembang dengan baik. Ardianti, dkk (2021) mengatakan bahwa pola asuh orang tua yakni salah satu cara bagaimana orang tua mendidik, mengasuh, mendisiplinkan anak dengan kasih sayang dari orang tua dan perhatian dari orang tua. Berdasarkan penjabaran diatas maka dapat disimpulkan bahwa pola asuh orang tua merupakan pola perilaku orang tua dalam melaksanakan perannya sebagai pengasuh, pendidik, pendamping bagi anaknya. Pola asuh yang dilakukan orang tua dapat mempengaruhi perkembangan diri anak.

Baumrind (dalam Ayun, 2017) mengkategorikan pola asuh menjadi tiga yakni (1) pola asuh otoriter, (2) pola asuh demokratis, dan (3) pola asuh permisif.

1. Pola asuh otoriter

Pola asuh ini ditandai dengan tekanan anak untuk patuh kepada semua perintah dan keinginan orang tua, kontrol yang sangat ketat terhadap tingkah laku anak, anak kurang mendapatkan kepercayaan dari orang tua, anak sering di hukum, apabila anak mendapat prestasi jarang diberi pujian atau hadiah.

2. Pola asuh demokratis

Pola asuh demokratis ditandai dengan adanya pengakuan orang tua terhadap kemampuan anak, anak diberi kesempatan untuk tidak selalu tergantung kepada orang tua. Anak diberi kesempatan untuk mengembangkan kontrol internal nya sehingga asedikit demi sedikit berlatih untuk bertanggung jawab kepada diri sendiri.

3. Pola asuh permisif
Pola asuh ini ditandai dengan adanya kebebasan tanpa batas pada anak untuk berperilaku sesuai dengan keinginannya sendiri, orang tua tidak pernah memberikan aturan dan pengarahan kepada anak, sehingga anak akan berperilaku sesuai dengan keinginannya sendiri walaupun terkadang bertentangan dengan norma sosial.

\section{Indikator Pola Asuh}

1. Indikator pola asuh demokratis

Desmita (dalam Rohmah, 2020) mengatakan bahwa indikator-indikator pola asuh demokratis. (1) Orang tua memberi kebebasan kepada anak tetapi masih dalam pengawasan orang tua. (2) Orang tua memberi kesempatan anak untuk mengungkapkan suatu pendapatnya kepada orang tua. (3) Orang tua memahami dan mendengarkan penjelasan anak apabila anak melanggar aturan.

2. Indikator pola asuh permisif

Desmita (dalam Rohmah, 2020) mengatakan bahwa indikator-indikator pola asuh permisif. (1) Orang tua memberikan kebebasan kepada anak untuk mengatur dirinya sendiri. (2) Orang tua membiarkan anak melakukan hal yang disukai dan cenderung menghindari konflik dengan anak. (3) Orang tua tidak memberikan hukuman kepada anak meskipun anak melanggar aturan dan melakukan kesalahan.

3. Indikator pola asuh otoriter

Desmita (dalam Rohmah, 2020) mengatakan bahwa indikator-indikator pola asuh otoriter. (1) Orang tua menuntut anak sehingga anak hanya mengikuti perintah orang tua. (2) Orang tua memberi hukuman fisik atau verbal apabila anak tidak menuruti orang tua. (3) Komunikasi tidak fleksibel antara orang tua dengan anak karena orang tua tidak merespon pendapat dan perasaan anak.

\section{Sikap Tanggung Jawab}

Tanggung jawab berasal dari dalam hati dan kemauan sendiri untuk melakukan kewajiban (Sukirman,). Aisyah (2014) menjelaskan tanggung jawab merupakan suatu sikap atau perilaku yang menuntut siswa untuk menanggung resiko atas segala tindakan dan ucapannya yang diterapkan 
dalam kehidupan sehari-hari terutama dalam hal belajar. Lickona (dalam Sadiyah,) berpendapat bahwasanya tanggung jawab adalah usaha yang dilakukan oleh individu untuk menjaga dirinya sendiri maupun menjaga diri orang lain sehingga ia menjadi individu yang dapat menjalankan kewajibannya untuk ikut serta dalam kegiatan yang diselenggarakan di masyarakat sehingga terciptalah kehidupan yang lebik baik lagi dengan masyarakat. Tanggung jawab merupakan buah sari sebuah motivasi dan dorongan semangat terhadap pertumbuhan menjadi dewasa, serta terhadap perbuatan yang menunjukkan kemandirian menurut Azerad (dalam Evany, 2016). Menurut Zubaedi (dalam Nuroniyah, 2018) tangung jawab merupakan sikap dan perilaku seseorang dalam melakukan tugas serta kewajibannya yang dilakukannya kepada diri sendiri, masyarakat, lingkungan, negara dan Tuhan Yang Maha Esa. Berdasarkan penjabaran diatas maka, dapat disimpulkan bahwa tanggung jawab merupakan sikap yang dimiliki individu untuk melakukan kewajibannya serta siap menangggung segala konsekuensi atas perkataan dan tindakan yang dilakukan.

\section{Indikator Sikap Tanggung Jawab}

Beberapa indikator sikap tanggung jawab menurut Mustari (dalam Aisyah, 2014) menjelaskan bahwa indikator orang yang bertanggung jawab yakni: (1) Memilih jalan lurus, (2) Selalu memajukan diri sendiri, (3) Menjaga kehormatan diri, (3) Selalu waspada, (4) Memiliki komitmen pada tugas, (5) Melalukan tugas dengan standar yang terbaik, (5) Mengakui semua perbuatannya, (6) Menepati janji, (7) Berani menanggung resiko atas tindakan dan ucapannya.

Menurut Mohamad Mustari (dalam Ery, 2015) menyebutkan indikator individu yang mempunyai tanggung jawab yakni: (1) Memilih jalan lurus, (2) Selalu berusaha untuk memajukan diri sendiri, (3) Menjaga kehormatan diri, mempunyai kewaspadaan, (4) Memiliki komitmen pada tugas yang telah diberikan kepadanya, (5) Melakukan dan menyelesaikan tugas dengan sebaik-baiknya, (6) Mau mengakui kesalahan yang telah diperbuatanya, (7) Selalu menepati janji, (8) Mempunyai keberanian menanggung risiko atas tindakan dan ucapannya.
Pada penelitian ini menggunakan beberapa indikator yakni: (1) Komitmen pada tugas, (2) Mengakui perbuatannya, (3) Berani menanggung resiko atas Tindakan dan ucapan, (4) Menepati janji.

\section{METODE PENELITIAN}

Penelitian ini menggunakan jenis penelitian kualitatif deskriptif. Subjek pada penelitian ini yakni empat anak umur 8-10 tahun, penelitian dilakukan tiga kali untuk mendapatkan data yang sesuai dengan kebutuhan peneliti, dan penelitian telan dilaksanakan di Desa paren Rt 03 Rw 02 Kecamatan Mayong Kabupaten Jepara. Teknik dan instrumen data yang dipakai oleh peneliti dalam penelitian ini yakni observasi, wawancara, dan dokumentasi. Observasi dilakukan menggunakan lembar pengamatan orang tua dan anak, wawancara dilakukan menggunakan lembar wawancara orang tua dan anak, dan dokumentasi berupa rekaman wawancara dan foto pada saat penelitian. Analisis data dalam penelitian ini menggunakan analisis data kualitatif yang merujuk pada konsep Miles dan Huberman yakni pengumpulan data, reduksi data, penyajian data, dan penarikan ksimpulan yang disajikan secara interaktif

\section{HASIL DAN PEMBAHASAN}

Hasil penelitian yang telah dilakukan pada penelitian ini didapatkan dari hasil observasi dan wawancara yang telah dilakukan oleh peneliti selama tiga kali penelitian mengenai pola asuh Orang Tua dalam Perkembangan Sikap Tanggung Jawab Anak di desa Paren Jepara. Penelitian ini dimulai dari bulan September 2020 sampai dengan bulan Mei 2021 dapat ditemukan beberapa temuan mengenai Perkembangan Sikap Tanggung Jawab Anak.

Pola asuh yang diterapkan orang tua kepada anak berbeda-beda sehingga berpengaruh dalam perkembangan sikap tanggung jawab anak. Menurut Azerad (dalam Evany, 2016: 3) tanggung jawab merupakan buah sari sebuah motivasi dan dorongan semangat terhadap pertumbuhan menjadi dewasa, serta terhadap perbuatan yang menunjukkan kemandirian. Lickona (dalam Sadiyah, 2017: 4) berpendapat bahwasanya tanggung jawab adalah usaha yang dilakukan oleh 
individu untuk menjaga dirinya sendiri maupun menjaga diri orang lain sehingga ia menjadi individu yang dapat menjalankan kewajibannya untuk ikut serta dalam kegiatan yang diselenggarakan di masyarakat sehingga terciptalah kehidupan yang lebik baik lagi dengan masyarakat.

Perhatian dan kasih sayang serta pengasuhan orang tua kepada anak dapat memberikan dampak yang baik bagi anak dalam perkembangan sikap tanggung jawabnya. Pola asuh orang tua dalam perkembangan sikap tanggung jawab anak di Desa Paren Jepara sebagai berikut.

1. Sikap Tanggung Jawab Anak EGK

Ibu (S) orang tua dari anak EGK menerapkan pola asuh otoriter yang mengakibatkan anak EGK memiliki sikap tanggung jawab yang rendah. Sikap tanggung jawab yang rendah juga berpengaruh pada prestasi anak di sekolah. Pada penelitian pertama sikap tanggung jawab anak baik karena pada saat wawancara anak tidak berbicara apa adanya sesuai apa yang dilakukannya sehari-hari, sedangkan pada penelitian kedua anak mulai berbicara sesuai apa yang dilakukannya sehari-hari dan kurang memiliki sikap tanggung jawab. Pada penelitian ketiga anak memiliki sikap tanggung jawab yang cukup baik dari penelitian kedua. Hal tersebut ditunjukkan dengan hasil observasi dan wawancara selama tiga kali penelitian yang memperkuat data dalam penelitian ini.

"Tidak, kadang setelah belajar buku saya masih di meja mbak."

"Saya menaruh mainan sembarangan."

"Tidak merapikannya mbak."

"Saya langsung ke kamar mandi pipis mbak."

(Wawancara tanggal 29 Maret 2021)

Hal tersebut tidak sesuai dengan indikator sikap tanggung jawab yang dipakai oleh peneliti yakni komitmen pada tugas. Hal tersebut mengakibatkan rendahnya hasil prestasi anak di sekolah. Sikap tanggung jawab anak harus tumbuh pada diri anak agar anak lebih memahami kewajibannya. Selanjutnya anak menyatakan bahwa.
"Berani mbak."

"Meminta maaf kepada teman."

(Wawancara tanggal 13 April 2021)

Hal tersebut sesuai dengan indikator sikap tanggung jawab yang dipakai oleh peneliti yakni mengakui perbuatannya. Hal ini penting karena anak harus berusaha bertanggung jawab atas kesalahan yang telah dilakukannya sendiri sehingga merugikan orang lain dan berusaha untuk tidak mengulangi kesalahannya kembali. Lalu pernyataan anak yang menyatakan bahwa.

\section{"Saya takut mendapat hukuman yang berat mbak." \\ "Saya akan diam mbak tidak berani berbicara."}

(Wawancara tanggal 29 Maret 2021)

Hal ini tidak sesuai dengan indikator sikap tanggung jawab yang dipakai oleh peneliti yakni berani menanggung resiko atas tindakan dan ucapan. Anak harus mengetahui jika dia melakukan kesalahan berarti dia harus siap dengan resiko yang harus ditanggungnya. Kemudian pernyataan anak yang menyatakan bahwa.

"Saya akan meminta maaf."

"Terkadang iya mbak."

(Wawancara tanggal 13 April 2021)

Hal ini cukup sesuai dengan indikator sikap tanggung jawab yang dipakai oleh peneliti yakni menepati janji. Anak diharapkan mampu berjanji menjadi manusia yang bertanggung jawab atas semua perbuatan dan kesalahannya dan berusaha tidak mengulangi kesalahannya tersebut. Anak mendapat pujian dari orang tua yang bisa menambah semangat anak untuk bersikap bertanggung jawab dan menepati janji.

2. Sikap Tanggung Jawab Anak NM

Ibu $(\mathrm{H})$ orang tua dari anak NM menerapkan pola asuh demokratis yang menjadikan anak memiliki sikap tangung jawab yang baik. Sikap tanggung jawab yang baik juga menjadikan anak berprestasi di kelas. Hal tersebut ditunjukkan dengan hasil observasi dan wawancara selama tiga kali penelitian yang memperkuat data dalam penelitian ini, 
Jurnal PAJAR (Pendidikan dan Pengajaran)

Volume 5 Nomor 6 November | ISSN Cetak : 2580 - 8435 | ISSN Online : 2614 - 1337

DOI : http://dx.doi.org/10.33578/pjr.v5i6.8190

"Iya, saya merapikannya agar rapi."

"Iya, karena kita harus membersihkan kamar tidur agar rapi."

(Wawancara tanggal 12 Maret 2021)

Hal tersebut sesuai dengan indikator sikap tanggung jawab yakni komitmen pada tugas. Anak bertanggung jawab dengan barang-barang miliknya sendiri yang harus dirapikan dan dirawat dengan baik. Anak juga bertanggung jawab untuk merapikan kamar tidurnya sendiri sehingga nyaman untuk istirahat dan tidur. Kemudian pernyataan anak yang menyatakan bahwa.

"Iya, karena itu kesalahan kita sendiri dan kita harus mengakui kesalahan itu."

"Kita harus bertanggung jawab atas kesalahan yang kita buat sendiri."

(Wawancara tanggal 12 Maret 2021)

Hal tersebut sesuai dengan indikator sikap tanggung jawab yakni mengakui perbuatannya. Anak berani mengakui perbuatannya yang salah dan berani untuk bertanggung jawab atas kesalahan yang dilakukannya.

Lalu pernyataan anak menyatakan bahwa.

"Iya saya siap dihukum."

"Iya, saya akan bertanggung jawab."

(Wawancara tanggal 30 Maret 2021)

Hal tersebut sesuai dengan indikator sikap tanggung jawab yang dipakai oleh peneliti yakni berani menanggung resiko atas Tindakan dan ucapan. Anak berani menanggung resiko atas kesalahannya dan tidak lari dari masalah yang telah dilakukannya. Anak berusaha mencari solusi dengan orang tua untuk menyelesaikan permasalahan yang telah dilakukan. Selanjutnya pernyataan anak yang menyatakan bahwa.

"Iya, saya janji mbak."

"Terkadang iya mbak."

(Wawancara 14 April 2021)

Hal tersebut sesuai dengan indikator sikap tanggung jawab yang dipakai oleh peneliti yakni menepati janji. Anak berjanji menjadi manusia yang bertanggung jawab atas semua perbuatannya dan anak mendapat pujian dari orang tua setelah menepati janjinya tersebut.

3. Sikap Tanggung Jawab Anak AAP

Ibu (S) orang tua dari anak AAP menerapkan pola asuh permisif yang menyebabkan anak AAP memiliki sikap tanggung jawab yang cukup baik. Sikap tanggung jawab juga berpengaruh pada prestasi anak di sekolah. Hal tersebut ditunjukkan dengan hasil observasi dan wawancara selama tiga kali penelitian yang memperkuat data dalam penelitian ini.

\section{"Iya mbak saya merapikan buku setelah belajar." \\ "Tidak, karena ingin cepat bermain dan sarapan."}

(Wawancara tanggal 13 Maret 2021)

Hal tersebut kurang sesuai dengan indikator sikap tanggung jawab yang dipakai oleh peneliti yakni komitmen pada tugas. Anak merapikan buku setelah belajar dan merawat mainannya sendiri tetapi anak tidak mau merapikan dan membersihkan tempat tidurnya sendiri dan masih bergantung kepada orang tua untuk membersihkan serta merapikan tempat tidurnya. Selanjutnya pernyataan anak yang menyatakan bahwa.

\section{"Temanku nakal, jadi aku membalasnya." "Meminta maaf mbak." \\ (Wawancara tanggal 31 Maret 2021)}

Hal tersebut kurang sesuai dengan indikator sikap tanggung jawab yang dipakai peneliti yakni mengakui perbuatannya. Anak membalas perbuatan nakal temannya dan anak tidak berani mengakui perbuatannya karena takut dimarahi oleh orang tuanya, tetapi anak berani bertanggung jawab dengan meminta maaf atas kesalahannya. Lalu pernyataan anak yang menyatakan bahwa.

\section{"Tidak karena saya takut dihukum." \\ "Aku akan bertanggung jawab." \\ (Wawancara tanggal 31 Maret 2021)}


Hal tersebut kurang sesuai dengan indikator sikap tanggung jawab anak yang dipakai oleh peneliti yakni berani menanggung resiko atas tindakan dan ucapan. Anak tidak mau dihukum atas kesalahannya sendiri tetapi anak meminta maaf dan bertanggung jawab dengan kesalahan yang dilakukannya. Selanjutnya pernyataan anak yang menyatakan bahwa.

\section{"Saya berani mbak."}

"Ada mbak."

(Wawancara tanggal 15 April 2021)

Hal tersebut sesuai dengan indikator sikap tanggung jawab yang dipakai oleh peniliti yakni menepati janji. Anak berani untuk bertanggung jawab dengan kesalahannya dan berjanji tidak mengulangi kesalahannya Kembali. Anak merasa bangga saat anak menepati janjinya sendiri untuk tidak melakukan kesalahan dan orang tua memberi reward kepada anak karena anak menepati janjinya.

4. Sikap Tanggung Jawab Anak DK

Ibu $(\mathrm{T})$ orang tua dari anak DK menerapkan pola asuh permisif yang menyebabkan anak DK memiliki sikap tanggung jawab yang cukup baik. Sikap tanggung jawab juga berpengaruh pada prestasi anak di sekolah. Hal tersebut ditunjukkan dengan hasil observasi dan wawancara selama tiga kali penelitian yang memperkuat data dalam penelitian ini.

"Iya saya merapikannya agar rapi mbak." "Ibu yang merapikannya mbak."

(Wawancara tanggal 14 Maret 2021)

Hal tersebut kurang sesuai dengan indikator sikap tanggung jawab yang dipakai oleh peniliti yakni komitmen pada tugas. Anak bertanggung jawab dengan barang-barang miliknya sendiri seperti merapikan buku setelah belajar dan merawat mainannya sendiri, tetapi anak tidak mau merapikan kamar tidurnya sendiri dan bergantung pada orang tua untuk merapikan dan membersihkan kamarnya. Selanjutnya pernyataan anak yang menyatakan bahwa.

"Terkadang tidak mbak."

"Dengan meminta maaf kepada teman."

\section{(Wawancara tanggal 01 April 2021)}

Hal tersebut kurang sesuai dengan indikator sikap tanggung jawab yang dipakai oleh peneliti yakni mengakui perbuatannya. Anak tidak mengakui perbuatannya yang salah saat dirumah tetapi anak berani bertanggung jawab dengan kesalahannya saat diluar rumah yakni dengan meminta maaf kepada teman dan mengakui perbuatan salahnya. Lalu pernyataan anak yang mengatakan bahwa.

\section{"Saya tidak mau dihukum mbak." \\ "Meminta maaf mbak."}

(Wawancara tanggal 16 April 2021)

Hal tersebut kurang sesuai dengan indikator sikap tanggung jawab yang dipakai oleh peneliti yakni berani menanggung resiko atas Tindakan dan ucapan. Anak melakukan kesalahan tetapi tidak mau dihukum dan takut dimarahi oleh orang tuanya, tetapi anak berani untuk meminta maaf untuk menebus kesalahannya. Selanjutnya pernyataan anak yang menyatakan bahwa.

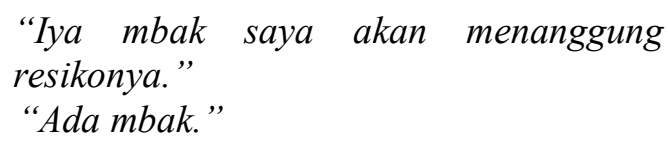

(Wawancara tanggal 16 April 2021)

Hal tersebut sesuai dengan indikator sikap tanggung jawab anak yang dipakai oleh peneliti yakni menepati janji. Anak berani menanggung resiko atas semua kesalahannya dan berjanji tidak mengulangi kesalahannya kembali. Anak merasa bangga karena telah menepati janji untuk tidak mengulangi kesalahannya kembali dan orang tua memberi reward kepada anak sebagai pujian karena anak tidak mengulangi kesalahannya lagi.

\section{SIMPULAN DAN REKOMENDASI}

Berdasarkan hasil temuan penelitian yang telah dilakukan oleh peneliti selama tiga kali penelitian mengenai Pola Asuh Orang Tua Dalam Perkembangan Sikap Tanggung Jawab Anak Di Desa Paren Jepara dapat diambil simpulan bahwa bentuk sikap tanggung jawab anak di Desa Paren Jepara berbeda-beda, hal ini dikarenakan pola asuh yang diterapkan orang tua kurang sesuai dengan 
anak. Hal tersebut berdasarkan hasil observasi dan wawancara yang telah dilakukan oleh peneliti selama tiga kali penelitian yang berdasar pada indikator sikap tanggung jawab yang dipakai peneliti. Anak pertama memiliki tanggung jawab yang rendah, hal ini dikarenakan kurangnya tanggung jawab anak dalam menyelesaikan masalahnya sendiri. Anak kedua memiliki tanggung jawab yang baik, hal tersebut dikarenakan tanggung jawab anak dalam menyelesaikan masalahnya dan bertanggung jawab dengan kesalahan yang dia lakukan. Sedangkan anak ketiga dan keempat memiliki sikap tanggung jawab yang cukup baik, anak masih malu untuk mengakui kesalahannya sendiri. Orang tua mampu menerapkan pola asuh yang sesuai kepada anak sehingga dapat membantu perkembangan sikap tanggung jawab dengan maksimal dan memberikan dampak yang baik bagi anak, orang tua maupun masyarakat sekitar karena orang tua dan keluarga adalah pendidik pertama anak. Masyarakat dapat membantu dalam perkembangan sikap tanggung jawab anak dengan baik karena lingkungnan masyarakat merupakan pendidik kedua setelah orang tua dalam memnatu perkembangan sikap tanggung jawab anak. Peneliti selanjutnya diharapkan dapat membahas lebih detail mengenai pola asuh orang tua dalam perkembangan sikap sosial anak dan dapat mengembangkan penelitian ini lebih dalam lagi mengenai pola asuh orang tua dalam perkembangan sikap tanggung jawab anak.

\section{DAFTAR PUSTAKA}

Aisyah, A., Nusantoro, E., dan Kurniawan, K. (2014). Meningkatkan Tanggung Jawab Belajar melalui Layanan Penguasaan Konten. Indonesian Journal of Guidance and Counseling: Theory and Application, 3 (3 SE-Articles). https://doi.org/10.15294/ijgc.v3i3.3783

Ardianti, S. D., Khamdun., \& Rositania, L.W. (2021). Pola Asuh Orang Tua Dalam Pembentukan Disiplin Belajar Anak Selama Pembelajaran Daring Di Desa Trangkil Rw 02. Jurnal Edukasi Tematik. $2(1), 30-42$.

Ardianti, S. D., Kanzunnudin, M., \& Pratiwi, Ika. R. Implementasi Project Based Learning
(PjBL) Berpendekatan Science Edutainment Terhadap Kreativitas Peserta Didik. Jurnal Refleksi Edukatika. 7 (2).

Ayun, Q. (2017). Pola Asuh Orang Tua Dan Metode Pengasuhan Dalam Membentuk Kepribadian Anak. Jurnal Inovasi Pendidikan Guru Raudhatul Athfal, V(1).

Damayanti, F. (2017). Pengaruh Pola Asuh Orang

Tua Terhadap Sikap sosial Anak Di

Kelompok B1 Tk Kemala Bhayangkari 01 Pim Staf Besusu Tengah.

Dewi, A. P. (2021). Penggunaan Skide Interaktif Pada Pembelajaran Daring Materi Substansi Genetik Untuk Meningkatkan Aspek Kognitif Siswa. Wasis: Jurnal Ilmiah Pendidikan. 2 (1), 56-61.

Ery, N. (2015). Tanggung Jawab Seorang Siswa SD Yang Terindikasi Berkepribadian Introvert. Skripsi. Universitas Negeri Yogyakarta.

Handayani, R. Imaniar Purbasari, dan Deka Setiawan. (2020). Tipe-Tipe Pola Asuh Dalam Pendidikan Keluarga. Refleksi Edukatika: Jurnal Ilmiah Kependidikan, $\mathrm{XI}(1)$.

Haris, I. N., Pengaruh Model Pembelajaran Kooperatif Tipe STAD Terhadap sikap Tanggung Jawab. Jurnal Ilmiah FKIP Universitas Subang. 4(2).

Kanzunnudin, M., Khamdun., \& Nadhifah, I. (2021). Analisis Peran Pola Asuh Orang Tua Terhadap Motivasi Belajar Anak. Jurnal Educatio. 7 (1), 91-96.

Muktadin, Z. (2010). Pola Pengasuhan dan Gangguan Kepribadian. Pesona PAUD, $\mathrm{I}(1)$.

Muslima. (2015). Pola Asuh Orang Tua Terhadap Kecerdasan Finansial Anak. Gender Equality: Internasional Journal of Child and Gender Studies, I(1).

Nuroniyah, S. (2018). Pengembangan Instrumen Pengukuran Sikap Tanggung Jawab Siswa Madrasah Aliyah. Jurnal Penelitian dan Evaluasi Pendidikan. 6 (2), 134-141.

Rohmah, F. (2020). Hubungan Pola Asuh Orang Tua Dengan Kedisiplinan Siswa Di Madrasah Ibtidaiyah (MI) Darul Ulum Pekanbaru. Skripsi. Universitas Islam 
Jurnal PAJAR (Pendidikan dan Pengajaran)

Volume 5 Nomor 6 November | ISSN Cetak : 2580 - 8435| |ISSN Online : 2614 - 1337

DOI : http://dx.doi.org/10.33578/pjr.v5i6.8190

Negeri Sultan Syarif Kasim Riau

Pekanbaru.

Sadiyah, H., Edi Rohendi, dan Leli Halimah.

(2017). Pengembangan Karakter

Tanggung Jawab Anak Melalui Kegiatan

Cooking Class. Jurnal Cakrawala Dini, VIII(1).

Shochib, M. (1998). Pola Asuh Orang Tua Untuk Membantu Anak Mengembangkan Disiplin Diri. Jakarta: PT Rineka Cipta.

Soraya, S. U. (2015). Pengaruh metode Multisensori Dalam MENINGKATKAN Kemampuan Membaca Permulaan Pada Anak Kelas Awal Sekolah Dasar. Jurnal PGMI. 2 (1), 38-48.

Sukirman. (2010). Seri Pengasuhan Positif. Jakarta : Kemendikbud. 